Vol. 27, No. 2, December 2020

P-ISSN: 0854-8919, E-ISSN: 2503-1023

Nationally Accredited Journal, Decree of MoHE No. 148/M/KPT/2020.

\title{
Simultaneous Elections in North Aceh Regency: An Islamic Perspective
}

\author{
Nasrullah Arull Yahya \\ Faculty of Syari'ah, Institut Agama Islam Negeri Lhokseumawe Aceh, Indonesia \\ E-mail: nasrullahyahya31@gmail.com
}

\section{ARTICLE INFO}

Keywords:

simultaneous elections;

quality of democracy; Islamic

perspective

How to cite:

Yahya, N. A. (2020). Cyber

Terrorism and its Prevention

in Indonesia. Jurnal Media

Hukum, 27(2), 177-183

Article History:

Received: 29-11-2019

Reviewed: 20-06-2020

Revised: 05-12-2020

Accepted: 31-12-2020

\begin{abstract}
The 2019 Simultaneous Regional Election has brought about some problems which threaten the quality of local democracy, especially in North Aceh Regency, Indonesia. The research aims at discussing the practice of Regional Election in North Aceh Regency from an Islamic perspective. In Islamic law, the Commission implements the General Election following the principles of justice and equal rights. This research is a normative and empirical study, which obtain data through library research and interviews with informants. While the data analysis used is descriptive. The results show that there are some problems in implementing the 2019 simultaneous elections in the North Aceh Regency from the Islamic perspective. First, there is a question on the Election Commission officers' neutrality in carrying out its duties and functions, such as taking sides to particular candidates or parties by way of inflating votes. The inflating votes are contrary to Islamic law principles, namely the principles of justice and equal rights; Second, the weakness of human resources in operating computers for inputting voter data and election result data. In Islamic law, the lack of qualified human resources impacts the inability to account for the mandate as caliph; and third, the inadequate facilities and infrastructure, both for offices (workspaces, desks, computers, and other supporting equipment) and non-available official vehicles. This situation is contrary to the objective of Islamic law, namely maqashid sharia, such as an essential element of life (dharuri), complementary aspect of life (haji), and accessories of life (tahsini) needs.
\end{abstract}

DOI: $10.18196 / j m h .20200150$

Copyright (C) 2020 JURNAL MEDIA HUKUM. All rights reserved

\section{Introduction}

General Election or abbreviated as PEMILU, is the mandate of the Law of the Republic of Indonesia Number 8 of 2012, that the Election Commission holds General Election every five years. The issuance of Law Number 7 of 2017 concerning General Elections has brought about significant changes to Indonesia's election law. The implementation 
of direct elections is the dynamic of government and development activities both in politics and in other fields ${ }^{1}$, and the life of the nation and State

The performance of simultaneous elections in 2019 is a special election as a new chapter for the Republic of Indonesia's future. The Special Election is that Indonesia is in a historical trajectory for the first time a presidential and vice-presidential election and the Election of legislative members are simultaneously held. ${ }^{2}$ This is one of the means of political democratization ${ }^{3}$ and a reflection of a society with freedom of expression and expresses its rights independently as citizens. ${ }^{4}$ The community is given space to play an active role and be part of the democratic process. Although substantially, their participation still tends to be procedural and momentum. ${ }^{5}$ Therefore, elections are a form of political involvement as a manifestation of people's sovereignty, governance from and for the people.

The participation of the people in elections is the most decisive part of the democratic political process in a country ${ }^{6}$ by voting; direct, general, free, confidential, honest, and fair (the principles of LUBER and JURDIL), both for the Election of president and vice president and for the determination of legislative members. ${ }^{7}$ Before becoming a legislative member, a person must go through several stages and requirements that must be met, determined by the KPU (according to the General Election Commission Regulation Number 15 of 2013) as a permanent candidate. A person who has been registered as a permanent candidate is known as a legislative candidate who will compete for the people's votes in the General Election.

The right to vote or vote is a fundamental right of every individual/citizen that must be guaranteed by the State. The guarantee of this right has been stated in both the Constitution (UUD 1945-Amendment) and the Law, namely Law No. 39 of 1999 concerning Human Rights and Law No. 12 of 2005 concerning the Covenant ratification on Civil and Political Rights. The election organizer (KPU) must avoid mistakes that can harm citizens so that citizens feel they are not being harmed and their political rights are not violated. In this case, the Government plays an essential role in guaranteeing citizens' voting rights and taking action against human rights violations in elections. ${ }^{8}$

\footnotetext{
1 Bachtiar, F. R. (2014). Pemilu Indonesia: Kiblat Negara Demokrasi Dari Berbagai Refresentasi, Jurnal Politik Profetik, 3(1), p. 2.

2 Haris, S., Surbakti, R., Bhakti, I. N., Isra, S., Ambardi, K., Harjanto, N., Nurhasim, M. (2014). Pemilu Nasional Serentak 2019, Accessed from http://www.rumahpemilu.com/public/doc/2019_10_09_executive summary pemilu serentak 2019, pdf, p. 15.

${ }^{3}$ Rusli, M. K. (1991). Pemilu Demokratis Kompetitif. Yogyakarta: PT. Tiara Wacana, p. 29.

4 Nurtjahjo, H., 2006. Filsafat Demokrasi. Jakarta: Bumi Aksara, p. 52.

5 Bachtiar, F. R. (2014). Pemilu Indonesia: Kiblat Negara Demokrasi Dari Berbagai Refresentasi. Jurnal Politik Profetik, 3(1), p. 2.

6 Powell JR, G. B. (2000). Elections as Instruments of Democracy (Majoritarian and Proportional Visions). New Haven: Yale University Press, p. 4.

7 Widodo, B. E. C. (2009). Sistem Pemilihan Umum Sebagai Upaya Strategis Untuk Membangun Sistem Politik Yang Demokratis. /320267977_sistem_pemilihan_umum_sebagai_upaya_strategis_untuk_membangun_sistem_politik_yang demokratis_1. Accessed date October 16, 2019. p. 2.

8 https://mediaindonesia.com/galleries/detail_galleries/10448-potensi-pelanggaran-ham-dalam-pemilu, 2019, Accessed date October 15, 2019. https://docplayer.info/72049773-Sarana-dan-prasaranakantor.html, Accessed date October 15, 2019.
} 
The Regency Election Committee (PPK), as the Election Organizer at the sub-Regency level -is a committee formed by the Regency/City KPU to carry out the Election subRegency level or by other names. PPK has a significant role and contribution to the country's democratic party's success every five years. Based on the duties, powers, and obligations mandated by the law, it is a reflection that the General Election was carried out safely, orderly, and successfully. Although this inevitability seems clear, the legislative elections (Pileg) and presidential elections (Pilpres) have not been designed to strengthen and increase the presidential Government's effectiveness. ${ }^{9}$

Even though the 2019 simultaneous election is based on the Constitutional Court Decision Number: 14 / PUU-11/2013 concerning Concurrent Elections, it is a new thing. It is the first time it has been held in the Republic of Indonesia. In other words, it is a unique and practical election. However, the implementation of the 2019 simultaneous elections in North Aceh Regency, which is given full authority to the District Election Organizer (PPK) has resulted in several problems both for internal PPK and external PPK personnel. This has an impact on the occurrence of violations and disputes from various political parties, such as voting. The PPK as an election organizer at the sub-Regency level should image itself as an independent, clean, honest, and fair institution. In this condition, the Government, members of parliament, and KPU commissioners should play an active role and be responsible for the success of the political system and election democracy so that the implementation of elections in the Republic of Indonesia does not always get caught up in opportunistic and pragmatic political games.

Strategic steps need to be taken as early as possible in terms of concept and implementation. The holding of elections once every five years as a form of democracy of a country is not tainted, especially in the recruitment of Districts Election Administrators (PPK) who have an attitude of neutrality and adequate human resources, have responsibilities in administering Elections, and so on. Meanwhile, the Government or through the election organizers at the central level (KPU) must be able to provide complete and adequate facilities and infrastructure so that future Elections can be carried out correctly and with dignity in all aspects compared to the 2019 simultaneous elections.

According to Islamic law, election implementation, although not included in the category of mandatory taklifi law, execution is permissible (permissible). Therefore, sharia does not determine what system to use, but it must comply with the provisions of the sharia to guide the life of the State. ${ }^{10}$ Maqashid sharia is formulated into five missions (religion, soul, mind, descent, and property) that must be maintained to preserve and ensure the realization of benefit for humans. ${ }^{11}$ Furthermore, the principles of honesty, justice, and equality of rights are essential things that must be maintained by election implementers. Besides, quality human resources are also needed who can adequately account for the mandate as caliph.

The above problems are fundamental reasons for holding this scientific study so that reliable data can provide positive solutions for the implementation of future elections.

\footnotetext{
9 Solihah, R. (2018). Peluang dan Tantangan Pemilu Serentak 2019 dalam Perspektif Politik. Jurnal Ilmiah Ilmu Pemerintahan, 3(1), p. 74.

10 Sodikin. (2015). Pemilihan Umum Menurut Hukum Islam. Jurnal Ahkam, XV(1), p. 62.

${ }^{11}$ Al-Syathibi, T.th., Al-Muwafaqat fi Ushul al-Syari'ah. Juz II, Cairo: Musthafa Muhammad, p. 2-3. See also al-Ghazali, T.th., Al-Mustasyfa min 'Ilm al-Ushul, Juz I, Bairut: Dar al-Fikr, p. 287.
} 
This study aims to explain the problems PPK and its anticipation for the implementation of the 2019 simultaneous elections in North Aceh Regency, as well as to analyze problems PPK in the implementation of simultaneous elections according to Islamic law.

\section{Method}

This research is empirical. The data used are primary data and secondary data. Primary data were obtained through interviews with informants, such as the PPK as the election organizer at the sub-district level, KIP Regency, and election participants. Meanwhile, secondary data were obtained through a literature study. While the data analysis technique used is descriptive analysis with a qualitative approach.

\section{Analysis and Results}

3.1. Problems PPK and their anticipation for the implementation of the 2019simultaneous elections in North Aceh Regency

Based on informants' data, several PPK problems emerged in the implementation of the 2019 simultaneous elections in the North Aceh Regency, which impacted the tarnishing of the five-yearly State democratic party. The PPK problems in the implementation of the 2019 simultaneous elections in North Aceh Regency, namely:

\subsubsection{The problem of neutrality of election administrators/PPK}

Most of the election organizers in the Kecamatan within North Utara Regency were not neutral, because generally election organizers at the Kecamatan level were recommended to become PPK by certain parties or parties. So that in reality, PPK has various personal or group interests with certain political parties, or because of money from certain candidates or certain political parties to do things outside the Election rules, to get more votes or vote inflated.

The problem of non-neutrality has occurred, such as in Seunuddon Regency, which raised (bulging) the votes of certain candidates by reducing the votes of other candidates. The issue became hot news and headlines in the Aceh print media. ${ }^{12}$ This news is not a mere issue. It has even been reported to the North Aceh Regency Panwaslih. In the trial, it was proven that the Seunuddon Regency PPK violated the election administration Panwaslih recommended that the Plenary Recapitulation be repeated..$^{13}$

A similar thing also happened in Geuredong Pasee Subdistrict to increase (inflate) the votes of voters to one candidate from a certain party. Although Plenary Recapitulation must make the Panwaslih decision, the technique used is different as in Seunuddon, namely voting for certain candidates from the party votes. ${ }^{14}$

The two problems stated above indicate that the non-neutrality of the Regency Election organizers can trigger conflicts between parties and candidates. In addition, that the stages do not match the Election stages determined by the KPU of the Republic of Indonesia.

\footnotetext{
12 Serambi Indonesia. https://aceh.tribunnews.com/2019/04/28/.

13 YS, Panwaslih North Aceh Regency, Interview result, 2019, Date October 27.

14 FQ, Panwaslih North Aceh Regency, Interview result, 2019, Date October 27. NS, PPK Geuredong Pasee District, Interview result, 2019, Date 25 October. Serambi Indonesia, 2019, Date April 30. p. 9.
} 


\subsubsection{PPK human resources problems}

The 2019 simultaneous elections need reliable human resources to achieve better goals. However, it is very different from the 2019 simultaneous election organizers in North Aceh Regency, where there is still many Sub Districts Election Organizer (PPK) personnel who are weak in technology as the inability to operate computers/laptops. Even though election organizers need computer/laptop skills, every activity and stage of the 2019 simultaneous election is closely related to data, both voter data and vote recapitulation data carried out with an application system.

Weak human resources for election organizers/PPK occurred in almost all subRegions in North Aceh Regency. ${ }^{15}$ According to ZF, this is motivated by several factors: the minimum number of highly educated people. They do not meet the administrative requirements to participate in selecting to become election administrators; lack of socialization and technical guidance from Election organizers/KIP at the Regency level.

With the 2019 simultaneous election organizers' weak human resources, the impact on the accumulation of all data on one election organizer. Even ironically, they asked for help from outside to recap the data in question. All of this is because the election organizers cannot control a computer/laptop, 16 including the chairman of PPK himself. ${ }^{17}$ Such a model affects the quality of the results and injures the Election itself, such as the emergence of political parties' objections.

The above problems contradict human resources theory because human resources mastery is an essential and capital factor in realizing work quality. Thus, the 2019 simultaneous elections in North Aceh Regency should have adequate human resources, not just filling in as election organizers at the District level.

\subsubsection{Office facilities and infrastructure problems}

Facilities are determinants of achieving maximum output, such as the availability of complete offices (workspaces) and supporting facilities (computers, printers, filing cabinets, tables, chairs, etc.). These needs are much different from the District Election Organizer (PPK) in North Aceh Regency, where offices (workspaces) are not adequate, and supporting facilities are inadequate with an enormous work volume. ${ }^{18}$

The improper and insufficient office facilities and equipment have affected the results of the PPK's work that is not optimal as mandated by the Election Law. The outcome achieved by the PPK in North Aceh District has disrupted election stages, such as voter data collection. The problem is that there are still voters who are not included in the

\footnotetext{
15 ZF, KIP North Aceh Regency, Interview result, 2019, Date October 27.

16 DS, PPK Baktya Barat Districts, Interview result, 2019, Date October 26. HD, PPK Dewantara Districts, Interview result, 2019, Date October 25. RW, PPK Simpang Keuramat Districts, Interview result, 2019, Date October 25. AL, PPK Langkahan Districts, Interview result, 2019, Date October 26; AB, PPK Baktya Districts, Interview result, 2019, Date October 26.

17 DH, KIP North Aceh Regency, Interview result, 2019, Date October 27.

18 TZ, PPK Samudera District, Interview result. 2019, Date October 27. MZ, PPK Syamtalira Bayu District, Interview result, 2019, Date October 24. AW, PPK Tanah Jambo Aye District, Interview result, 2019, Date October 24..
} 
final voter list (DPT), resulting in a lawsuit from election participants (political parties). The unregistered voters are supporters of one of the eligible participants. ${ }^{19}$

In addition to facilities and infrastructure problems, the 2019 simultaneous elections are very far from the 2014 elections. The 2019 simultaneous elections do not budget for vehicle rental funds, but only transportation funds are provided in SPPD for several official trips ( \pm 16 times) a year. ${ }^{20}$ Whereas in the 2014 Election, the election committee at the District level was given a budget to rent vehicles for transportation.

Based on the PPK Secretary's considerations, the PPK official travel budget in North Aceh Regency, which was allocated to five Election Committees, is logically inadequate because the geographical location of North Aceh Regency is extensive. Some Districts are very far from the Regency Independent Election Commission (KIP) secretariat office. Likewise with official trips to gampongs (villages), where some gampongs (villages) are located very far from the PPK secretariat, so it takes a long time to travel to their destination.

Regarding the PPK official trip to the KIP Regency secretariat office, according to the PPK Secretary's statement above, it is illogical because sometimes the need is more than five times a month. So when multiplied by the official trips \pm 16 times a year, it is not relevant to the working conditions of PPK, which are urgent and immediate.

The problems experienced by PPK in North Aceh Regency are not relevant to the theory of facilities, where office work is very dense and requires proper support. Office facilities are an integral part of all activities or work activities that have a function and role in achieving goals.

The three discussions of PPK problems in the implementation of the 2019 simultaneous Election above need logical and concrete anticipation as early as possible so that the performance of future elections will be better than the 2019 Election by taking into account the principles of democratic elections and human resources. Election implementers who are capable and accompanied by complete facilities and infrastructure. As for the anticipation of problems PPK in the implementation of the General Election simultaneously as follows:

\subsubsection{The neutrality of PPK}

A person can be declared neutral if he does not take sides with two or more people or takes sides with organizations or institutions in determining something, for example, a political party organization. ${ }^{21}$ Neutral can also be interpreted as; an impartial attitude and not taking sides with one group; not discriminatory; sterile from group interests; and is not influenced by political parties' interests. ${ }^{22}$

\footnotetext{
${ }^{19}$ MT, PPK Pirak Timu District, Interview result, 2019, Date October 24. SL. Participants Elections, Interview result, 2019, Date October 25.

20 AD, Secretary of PPK Baktya District, Interview result, 2019, Date October26 . NI, Secretary of PPK Samudera District, Interview result, 2019, Date October 24. LR, Secretary of PPK West Baktya District, Interview result, 2019, Date October 26.

21 Dispen. Netralitas PNS dalam Pilkada.http://dispenmaterikuliah.blogspot.co.id/2011/07/ netralitaspns-dalam-pilkada.html, Accessed 2019, Date October 16.

22 Anonimous. Netralitas Pegawai Negeri Sipil. https://docs.google.com/ document/d/1svE SXQZsGw01bAlGVPKTZYRJvHRgdMyr158XE 4RsUyU/edit\#!, Accessed 2019, Date October 16.
} 
In the Big Indonesian Dictionary ${ }^{23}$, neutrality is a neutral, impartial, and free State and attitude. ${ }^{24}$ Neutrality is an essential principle in carrying out public service tasks, government tasks and development tasks. ${ }^{25}$ Meanwhile, the principle of neutrality is that every employee of the state civil apparatus does not take sides from any form of influence and does not take sides with anyone's interests as regulated in the General Elucidation of Article 2, Letter f of Law No. 43 of 1999.

The election management institution is the party responsible for the implementation of a fair and smooth election. In general, the election organizer's responsibility is to implement the electoral process outlined by the laws and regulations. The election process includes the pre-voting stage, the voting stage, and the post-voting stage. ${ }^{26}$

The implementation of elections is an important moment for the democratic process. Given the importance of elections, the implementation of elections must be prevented from violations/crimes that hinder achieving its own election goals. The international standard of democratic elections has emphasized fifteen standards, one of which is the existence of legal guarantees ${ }^{27}$ so that these institutions can work independently. The independence of election management institutions is an essential issue because election administration machines make and implement decisions that can affect the election results.

The Institute for Democracy and Electoral Assistance has formulated several important issues in the formation of election management institutions. They are including. First, the structure means the election law must establish a central or national level administering institutions with authority and responsibility exclusive to lower institutions. Second, authority and responsibility. Third, composition and qualifications; Fourth, the term of office; Fifth, financing; Sixth, duties, and functions. The obligations and tasks of the EMB include; $a$. Ensure that officials and staff responsible for the administration of elections are appropriately trained and act reasonably and independently of any political interest; $b$. Ensure that voting procedures are developed and disseminated to the voting public; $c$. Ensure that voters are informed and educated about the electoral process, contesting political parties and candidates; $d$. Ensure voter registration and updating of voter lists; $e$. Ensure the confidentiality of voters; $f$. Ensure the integrity of ballots using specific measures to prevent unauthorized voting; and $g$. Ensuring the integrity of the transparent vote-counting process, tabulating and counting votes. ${ }^{28}$

The Chairperson of the PPK's duties and powers and its members are regulated by legislation, namely Law No. 7 of 2017 concerning General Elections. The responsibilities and authorities of PPK members are; First, assist the Chairperson of the PPK in carrying out their duties; Second, carry out tasks in accordance with the

\footnotetext{
23 Tim Redaksi (2003). Kamus Besar Bahasa Indonesia. Jakarta: Balai Pustaka, p. 780.

24 Rusliandy. Netralitas Pegawai Negeri Sipil. http//rusliandy.blogspot. co.id/2009/06/netralitas-pegawainegeri-sipil.html, Accessed 2019, Date October 15.

25 Mokhsen, N., et.al. (2018) Pengawasan Netralitas Aparatur Sipil Negara, Buku 1, Edisi 1, Komisi Aparatur Sipil Negara, p. 2.

26 Winardi. (2010). Menyoal Independensi dan Profesionalitas Komisi Pemilihan Umum Daerah Dalam Penyelenggaraan Pemilu Kepala Daerah. Jurnal Konstitusi, III(2), p. 51.

27 International DEA. (2002)., International Electoral Standards, Guidelines for Reviewing the Legal Framework of Elections. Stockholm: International Institute for Democracy and Electoral Assistance, p. 39-47.

28 International DEA. (2002)., International Electoral Standards, Guidelines for Reviewing the Legal Framework of Elections. Stockholm: International Institute for Democracy and Electoral Assistance, p. 39-47.
} 
applicable laws and regulations; Third, provide opinions and suggestions to the Chairperson of the PPK for consideration; Fourth, in carrying out their duties, PPK members are accountable to the Chairperson of the PPK. In addition, PPK, in carrying out its duties and functions, must comply with and comply with the code of conduct for election administration, which contains; principles of independence and fairness, principles of legal certainty, principles of honesty, openness and accountability, principles of public interest, principles of proportionality, principles of professionalism, principles of efficiency and effectiveness and principles of order.

In the context of organizing elections, the Constitutional Court threatened general election organizers, especially the regional KPU, because the Court suspected them of depriving candidates of regional head candidates or disqualifying them. So they did not have a legal position or legal standing to file a lawsuit to the Constitutional Court. The Constitutional Court's extensive interpretation of prospective candidates, or giving them legal standing to challenge the Constitutional Court, if such problems persist. ${ }^{29}$

The neutrality problem of PPK is related to the political dynamics that are very prone to abuse of the commissioners' authority, specific political interventions, and even the professional capacity of the commissioners themselves in certain districts. The nonneutrality of PPK requires clear, transparent, systematic institutional reform, primarily through measures to strengthen laws, including norms of prohibition and firm sanctions for any party who tries to intervene in PPK. Includes transparent reporting of funds and audited by an independent auditor.

\subsubsection{PPK Human Resources}

According to Nawawi human resources are potential assets and function as nonmaterial or non-financial capital in a business organization, which can be realized into the physical and non-physical real potential in realizing the company's existence. ${ }^{30}$ According to Miller, human resources are crucial factors in carrying out development such as natural, material, and financial resources will not provide optimal benefits for welfare improvement if the availability of human resources factors does not support it, both in quality and quantity. ${ }^{31}$

According to Megginson, the term human resources, Mattews and Banfield is a term used to describe an integrated and holistic approach in changing the behavior of people involved in a work process, using a series of relevant techniques and strategies. ${ }^{32}$ Besides, human resources are part of management, which focuses on human problems in work relations with their duties without neglecting other production factors. Human resources management is defined as empowerment, assessment, remuneration, and management of each organization's individual members. Hasibuan states that human resource management is the science and art of

\footnotetext{
29 Winardi. (2010). Menyoal Independensi dan Profesionalitas Komisi Pemilihan Umum Daerah Dalam Penyelenggaraan Pemilu Kepala Daerah. Jurnal Konstitusi, III(2), p. 51.

30 Nawawi, H. (2006). Manajemen Sumber Daya Manusia untuk Bisnis yang Kompetitif. Yogyakarta: Gadjah Mada University Press, p. 40.

31 Miller, P. H. (2000). Theories of Developmental Psychology, 3rd ed. New York: W. H. Freeman and Company, p. 97.

32 Megginson, J-M., \& Banfield. (1999).Human Resource Development. London: Kogan-Page Limited, p. 96.
} 
managing the workforce's relationships and roles to be effective and efficient in helping achieve the goals of companies, employees, and society. ${ }^{33}$

The important task of management is to regulate and manage human factors as optimally as possible to obtain adequate and efficient results by compiling, developing, and implementing human resources development programs following the needs of institutions, companies, and so on. Management that deals explicitly with and manages the human element is called human resources management.

Human resources management is a process that consists of planning, organizing, leading, and controlling activities related to job analysis, job evaluation, procurement, development, compensation, promotion, and termination of employment to achieve predetermined goals. Human resources in an organization need to be managed professionally to balance employees' needs and abilities and the demands of the organization.

The existence of human resources management for the success of an organization is very decisive. However, it cannot be denied that today the world is in an era of modern globalization. Much human power has been replaced by sophisticated equipment, such as automatic machines, computers, and others that effectively and efficiently move. Human resources management's role is to realize organizational goals, namely their ability and seriousness to work effectively and efficiently. If not followed by morale and employee discipline, knowledge and skills are not meaningful in realizing its vision and mission.

In the management concept, humans are expected to be willing to make optimal use of their energy to increase productivity, followed by the creation of good and clear Job Descriptions and Job Specifications. Therefore, improving human resources quality makes a creative institution master and developing science, technology, and arts (IPTEKS) and have morality. With creativity, they give birth to dynamism and positive solutions when faced with difficulties or problems.

Thus, human resource management is a process of activities carried out by the leadership to obtain, maintain and develop manpower, both in terms of quality and quantity, by taking into account the nature and nature of humans as members of the organization concerned appropriately and efficiently. In other words, the success of managing an organization and the human resource utilization activities very much determine their activities.

Some experts define quality with various interpretations. Juran defines quality simply as 'suitability for use'. ${ }^{34}$ The philosophy of building quality as a system, the definition of quality is broader; First, the perfect degree: contains a comparative meaning to a certain product level. Second, the level of quality: has the definition of quality for technical evaluation. Third, suitability for use: the ability of the product or service to provide satisfaction to customers.

Nowadays, the word quality has various interpretations, cannot be defined singly, and is very dependent on the context. Several definitions of quality based on the context need to be distinguished on the basis of; organization, events, products, services,

33 Hasibuan, M. S.P. (2010). Manajemen Sumber Daya Manusia (Edisi Revisi). Cet. XII, Jakarta: PT. Bumi Aksara, p. 10.

34 Juran, M. J. (1989). Juran on Quality By Design. York: McMillan Company, p. 16-17. 
processes, people, results, activities, and communications. Dale concludes several survey results that focus on the perception of the importance of product and service quality. This includes a wider public perception of the quality of products and services, increasing views, top management roles, non-negotiable quality, and quality encompassing all things, increasing productivity. Quality affects better performance on the market. Quality means improving business performance, non-quality costs are high, consumers are king, quality is the way of life..$^{35}$

The quality of work, according to Edwin, is an outcome that can be measured by the effectiveness and efficiency of work carried out by human resources or other resources in achieving company goals or objectives efficiently and adequately. Although every organization has different views on the quality of employee work, effectiveness and efficiency are standard measures. ${ }^{36}$

Wungu and Brotoharsojo believe that quality is any form of a unit of measure related to the quality or quality of work and expressed in numerical calculations or which can be matched with numbers. ${ }^{37}$ Meanwhile, according to Wilson and Heyel, the quality of work shows how an employee's rate in carrying out his duties includes accuracy, completeness, and neatness. ${ }^{38}$

Human resources, especially PPK, need to be developed continuously to obtain quality work in the real sense; namely, the work carried out will produce something desired. Quality is not only proficient but fulfills all the qualitative requirements that the job demands so that the job can actually be completed as planned.

\subsubsection{Office Facilities and Infrastructure}

Means are anything that can be used as a means to achieve the goal or purpose. ${ }^{39}$ Therefore, office facilities play an important role in the process of carrying out office activities, and they are directly used as a tool or moving object in the process of completing office tasks and work. Article 1 of Regulation of the Minister of Home Affairs Number 7 of 2006 concerning the Standardization of Work Facilities and Infrastructure for Regional Government explains that office work facilities are facilities that directly function as a support for the implementation of regional Government in achieving the designated facilities, including: office space, work equipment and official vehicles.

Meanwhile, the definition of infrastructure etymologically means an indirect means to achieve goals. ${ }^{40}$ According to the Big Indonesian Dictionary, everything is the main support for implementing a process. ${ }^{41}$ Thus, office infrastructure can be defined as facilities for objects (immovable property) that are used to support office facilities in achieving the goals of a business or organization. The facilities and infrastructure are

\footnotetext{
${ }^{35}$ http://www.damandiri.or.id/file/setiawanwicaksonounbrawbab2.pdf. Accessed 2019, Date October 15.

36 Edwin, F. B. (2009). Personal Management. Sixth Edition, USA McGraw-Hill: International Book Company, p. 28.

37 Wungu \& Brotoharjo. (2010). Tingkatkan Kinerja Perusahaan Anda Dengan Merit Sistem. Jakarta: Raja Grafindo Pustaka, p. 57.

38 Wilson \& Heyel. (2000). Hand Book Of Modern Office Management and Administration Service. New Jersey:

Mc Graw HillInc, p. 101.

${ }^{99}$ Editorial Team. (2008). Kamus Besar Bahasa Indonesia. Jakarta: Balai Pustaka, p. 127.

40 Daryanto. (2000). Administrasi Pendidikan. Jakarta: Rineka Cipta, p. 51.

41 Tim Redaksi. (2008). Kamus Besar Bahasa Indonesia. Jakarta: Balai Pustaka, p. 1099.
} 
not too different because both are interrelated. Distinguish both facilities and infrastructure, facilities are more aimed at moving objects, while infrastructure is more aimed at objects that are not moving.

In the Regulation of the Minister of Home Affairs Number 7 of 2006 concerning Standardization of Suggestions and Work Infrastructure for Regional Government. Article 1 explains that office infrastructure is a facility that indirectly functions to support the implementation of an apparatus work process in improving performance in accordance with their duties and responsibilities, such as office buildings, office houses, and agency houses. Infrastructure is needed in permanent or permanent activities such as buildings, fields, halls, and so on in an organization or company.

The types of office facilities and infrastructure are:

1. Office equipments or supplies.

2. Office equipment or supplies are tools or materials used to assist in implementing office work to produce a job that is expected to be completed more quickly, precisely, and well.

3. Office equipment or supplies can be divided into two, namely; First, office equipment or equipment, seen from its shape, is divided into three, among others: Sheet or sheet form (paper), non-sheet form (not sheet paper), Book form; Second, office equipment or supplies are seen from their use are divided into two, among others; Consumable goods are office items or objects that are used for only one or several times or the goods are not durable; Non-consumable items are office items or objects that are durable in use.

4. Office machines are tools used to collect, record, process information materials in office work that work mechanically, electrically, and magnetically.

5. Office communication machines are office facilities used to communicate both within the organization itself and outside the organization.

6. Office furniture is office objects made of wood or iron to help carry out office work tasks.

7. Office interiors are office objects that are used to add a pleasant atmosphere so as to provide enthusiasm and comfort in completing work.

8. Office layout is the arrangement of office space and arrangement of office equipment and furniture according to the floor area and available office space so as to provide satisfaction and comfort to employees at work. ${ }^{42}$

The three discussions above are a model to anticipate the three PPK problems in implementing the 2019 Concurrent Election in North Aceh Regency. The anticipation model put forward is based on existing concepts and theories so that it becomes an optimistic hope and solution for the administration of elections in carrying out its duties and obligations. By sticking to the existing concept, every task that is carried out will produce a good and satisfying output. For this reason, the democracy of a country will shine when election administrators carry out their duties and obligations properly, honestly, and fairly. Otherwise, the democracy of a country becomes bleak if the

42 https:/ / docplayer.info/72049773-Sarana-dan-prasarana-kantor.html. Accessed 2019, Date October 15. 
election organizers do not carry out their duties and responsibilities properly or behave fraudulently.

\subsection{Problems of PPK in Implementation simultaneous elections according to Islamic law}

In Islamic law, the implementation of elections is not classified into the category of taklifi law, which is compulsory but instead is permissible. Election to elect people's representatives who sit in the legislative body, Islamic law does not determine what system is used, but its implementation is in accordance with the provisions of Islamic law. This is intended to provide a guideline in state life. ${ }^{43}$ Although it is not explicitly regulated regarding constitutional issues (Election mechanism), nor does it separate between religion and State, in Islamic law, namely through the understanding of fiqh siyasah there is a set of values or basic principles regarding constitutional problems. ${ }^{4}$

Concerning constitutional issues, such as in the holding of elections, Islamic law focuses on election implementers at least three things according to the problem PPK in the implementation of the 2019 simultaneous elections in North Aceh Regency, which are as follows:

\subsubsection{The principle of justice (al-'adalah) and equality (al-Musawat) rights.}

The principle of justice (al-'adalah) is a principle that is impartial and proper, equal, equalizing, balanced, and so on. ${ }^{45}$ Sayyid Quthub, as quoted by Pulungan, stated that justice is inclusive, not exclusive to certain groups, even if those who determine justice are Muslims for non-Muslims. ${ }^{46}$ According to the principle of justice, humans are obliged to uphold Allah's laws and are prohibited from applying other laws that are contrary to God's laws. One of these provisions is listed in the QS. 5: 48-49.

Being fair is the Creator's methodology and is the law of Allah. One of the reasons Allah sent His Apostles and lowered His books so that humans on earth can act reasonably. ${ }^{47}$ Fairness in an Islamic State aims to uphold religion and create the benefit of the people and as evidence for the people's best. Thus, the principle of justice referred to here is the same treatment by election administrators to election participants/candidates for legislative members or certain parties without any specialization or discrimination, such as balloting votes against certain participants and or parties.

The principle of equality (al-Musawat) rights is the Fulfillment of the rights and obligations inherent in every human being without discrimination. According to this principle, humans' position is equal in Allah's eyes, and the highest rank is a cautious person. One of these provisions is listed in the QS. 49: 13. Subhi Mahmasani is a Muslim thinker from Egypt who explains a lot about human rights in his book huquq al-Insan fi al-Islam. According to him, this concept in Islam is based on equal rights and obligations between human beings, which is based normatively on the principles of

\footnotetext{
43 Sodikin. (2015). Pemilihan Umum Menurut Hukum Islam. Jurnal Ahkam, XV(1), p. 62.

44 Sjadzali, M. (1991). Islam dan Tata Negara. Jakarta: UI Press, p. 1-3.

45 Ka'bah, R. (2005). Politik dan Hukum dalam al-Qur'an. Jakarta: Khairul Bayan, p. 82.

46 Pulungan,J. S. (1994). Prinsip-prinsip Pemerintahan dalam Piagam Madinah: Ditinjau dari Pandangan alQur'an. Cet. I, Jakarta: RajaGrafindo Persada, p. 225.

47 Khaliq, F. A. (2005). Fikih politik Islam. Penerjemah Faturrahman A. Hamid, Jakarta: Amzah, p. 204.
} 
equality (al-Musawat) and freedom (al-hurriyat) in shari'ah norms that are the most fundamental principles of dignity humanity. This theory of equality of rights is the basis for the formulation of the concept of legal aid in Islamic law. 48

The three principles above are fundamental to be put into practice by election administrators in carrying out their duties and functions, namely presenting fair and democratic elections. The concept of democracy is a different keyword in political science because democracy is currently touted as an indicator of a country's political development. ${ }^{49}$ The three principles above are fundamental to be put into practice by election administrators in carrying out their duties and functions, namely presenting fair and democratic elections. The concept of democracy is a separate keyword in the field of political science because democracy is currently touted as an indicator of a country's political development.

Based on the principles in Islamic law above, the implementation of elections in state life should be aimed at justice, goodness, and benefit for the survival of the people themselves. It is primarily for legislative candidates and or certain parties whose votes have been devolved to legislative candidates and certain other parties by the implementing party for the District Election or PPK. PPK behavior like this can be detrimental to certain candidates and or parties even though voting means having the same rights (the principle of equal rights) with other candidates and or parties. This means that by inflating the votes to certain candidates and or parties, PPK has punished certain parties, and even worse, PPK betrayed its oath as election executor. Therefore, the application of the principles of Islamic law relating to the implementation of elections should be adjusted to the mechanism that wants it and according to the demands of the principles of Islamic law. The main objective is to eliminate harm and give priority to the public benefit. ${ }^{50}$

\subsubsection{Strengthening Human Resources}

Human resources are the greatest power in processing all the resources that exist on earth and are deliberately created by Allah for the benefit of mankind. Having qualified human resources will be able to account for the mandate as a caliph properly. Al-Qur'an affirms that humans are responsible beings who were created with divine attributes, according to QS. 2:30, QS. 6: 165, QS. 16: 93 and QS. 17:34.

The Human Resources problem is fundamental in the context of organizational, community, and state life. Without having qualified human resources, whatever the vision, mission, targets, goals, work plans that have been well prepared, mature and ideal, will not be effective and function optimally. Therefore, a progressive organization, company, nation, religion, and even civilization can be assured of having quality, innovative and productive human resources, so that in their history they are known, strong and surviving for decades, which then become an example for the next generation.

\footnotetext{
48 Mahmasani, S. T.th. Huquq al-Insan fi al-Islam. Cairo: Dar al-Maktabah and see Mahmasani, S. (1982). "Adaption of Islamic Jurisprudence to Modern Social Needs" in Donohue, J. J., \& John L. Esposito, J. L., eds., Islam in Transition: Muslim Perspectives. Oxford: Oxford University Press, p. 181-187.

49 Dahl, R. (1989). Democracy and its Critics. New Haven: Yale University Press, dan Birch, A.H. (1993). The Concepts and Theories of Modern Democracy. London: Routledge.

50 Al-Jauziyah, I. Q. (2000). I'lam al-Muwaqqi'in. in Usman, M. (2000). Kaidah-kaidah Ushuliyah dan Fiqhiyyah. Jakarta: Gema Insani Press.
} 
Human Resource Development is very important, and it is not only from the point of view of science and technology but no less important is from the spiritual dimension in human resources development. The quality of human resources will not be perfect without religious mental-spiritual toughness, but holding religious values will be more resilient spiritually. So that then they will have a more spiritual responsibility for science and technology. Conversely, human resources are not accompanied by loyalty to religious values but will only lead people to pursue worldly pleasures or mere hedonism. ${ }^{51}$

The direction and goal of human resource development based on the Islamic concept is to form human beings with noble morals, who always worship Allah, spread mercy for the universe, and devote themselves to Allah. Moreover, as caliphs on earth, we must maintain God's mandate always to be human beings who have potential resources and develop them to achieve prosperity in this world and the hereafter.

In connection with the problems PPK in the implementation of the 2019 simultaneous elections in North Aceh Regency, Islamic law, through arguments, recommends having qualified human resources in both spiritual and spiritual dimensions. The formation of noble and fearful morals to Allah is an output in developing human resources by adhering to religious values and maintaining the mandate as a caliph on this earth.

\subsubsection{Fulfillment of facilities and infrastructure}

In Islamic law, the Fulfillment of facilities and infrastructure is a critical necessity to realize humans/people's benefit. ${ }^{52}$ To make it happen, al-Syathibi divided maqashid into three levels, namely, Maqashid dharuriyat, maqashid hajiyat, and maqashid tahsinat. Dharuriyat means that it must exist for the servant's benefit, which if it does not exist, it will cause damage, for example, the pillars of Islam. Hajiyat means something needed to get rid of narrowness, such as relief (rukhsah) of not fasting for the sick. Tahsiniat implies something that is taken for the good of life and avoids badness, such as noble morals, eliminating uncleanness, and covering one's genitals.

Substantially, maqasid al-syari'ah contains benefits, both in terms of maqasid al-syari' (God's purpose) and maqasid al-mukallaf (Mukallaf's goal). Viewed from the point of view of God's purpose, Maqashid al-Syariah contains four aspects, namely: 1). The original purpose of Shari' (Allah and His Messenger) established the sharia, namely for the benefit of mankind in this world and the hereafter. 2). Establishment of sharia as something that must be understood. 3). Establishment of sharia as taklifi law that must be implemented. 4). The determination of Shari'ah to bring people under the protection of the law is to avoid the following lust.

Likewise, from the point of view of maqasid al-mukallaf, maqashid al-Sharia contains four aspects as well, namely: a) Maslahah discussion, meaning, level, characteristics, and relativity or absolutes. $b$ ). Discusses the linguistic dimension of problem taklifs that are ignored by other jurists. An order that is a taklif must be understood by all its subjects, not only in words and sentences but also in linguistic and cultural understanding. AlSyathibi discussed this problem by explaining dalalah asliyah (essential meaning) and ummumiyah (understandable to ordinary people). c). Analysis of the purpose of taklif

51 Haluty, D. (2014). Islam dan Manajemen Sumber Daya Manusia yang Berkualitas. Jurnal Irfani, 10(1).

52 Al-Syathiby, T.th. Al-Muwafaqat fi Ushul al-Syari'ah, Jilid II, Cairo: Mustafa Muhammad, p. 2-3. 
concerning abilities, difficulties, and others. d). Explanation of the huzuz aspect in relation to hawa and ta'abud.

Fulfillment of facilities and infrastructure is a necessity that cannot be avoided. Therefore, this need's problem is reflected in three levels in the maqashid, namely Dharuri, Hajj and Tahsini. The relationship between the three levels in maqashid and PPK problems in the implementation of the 2019 simultaneous elections, such as the need for facilities and infrastructure, is very relevant. Although not feasible and not provided, the availability of offices (workspace) and vehicles is included in the Dharuri level. Meanwhile, the availability of computers, printers, filling cabinets, tables, and chairs is the Hajj stage, while other complementary materials are the tahsini level. As formulated thoroughly by previous scholars, the three components of the maqashid level are for the benefit of religion and the State.

\section{Conclusion}

Election administration is a reflection of democracy for a nation and a State. The implementation of the 2019 simultaneous Election in the Republic of Indonesia, even though it is a new and first-time election, is a unique and practical election. Still, fraud continues to occur and seems unable to be eradicated by the authorities, and has been entrenched in the nation's democratic party Republic of Indonesia. Because every Election is held, fraud still occurs, especially on the District Election organizers (PPK).

The implementation of the 2019 simultaneous elections in the North Aceh Regency has attracted various groups' attention regarding the General Election implementation. This is because the Election at the sub-district/PPK level is not neutral in carrying out its duties and functions, thus injuring the people's democratic party. The nonneutrality of PPK is a big problem in the context of organizing the General Election. It is because the PPK has inflated the votes of certain candidates, whether the votes were taken from candidates from other parties or votes from those from their party -which is strongly suspected that the PPK received bribes. Through its principles, Islamic law prohibits it because it is not in accordance with the principles of justice and equal rights.

Another problem PPK in implementing the 2019 Concurrent Election in North Aceh Regency is the lack of human resources and proper facilities and infrastructure. Regarding PPK human Resources, most of the District Election/PPK implementers are unable to operate a computer/laptop, so this is contradictory to Islamic law, which requires quality human resources. Meanwhile, facilities and infrastructure can indeed be said to be inadequate, both for offices and other equipment. This contradicts the concept of maqashid, namely dharuri, haji, and tahsini to achieve human welfare.

\section{References}

Books:

Al-Ghazali. T.t. Al-Mustasyfa min 'Ilm al-Ushul. Juz I. Dar al-Fikr.

Al-Jauziyah, I. Q. (2000). I'lam al-Muwaqqi' in in Usman, M. (2000). Kaidah-kaidah Ushuliyah dan Fiqhiyyah. Jakarta: Gema Insani Press.

Al-Syathibi, T.t. Al-Muwafaqat fi Ushul al-Syari'ah. Juz II, Musthafa Muhammad. 
Birch, A.H. (1993). The Concepts and Theories of Modern Democracy. London: Routledge.

Dahl, R. (1989). Democracy and its Critics. New Haven: Yale University Press

Edwin, F. B. (2009). Personal Management. Sixth Edition, USA McGraw-Hill: International Book Company.

Hasibuan, M. S.P. (2010). Manajemen Sumber Daya Manusia (Edisi Revisi). Cet. XII, Jakarta: PT. Bumi Aksara.

Institute for Democracy and Electoral Assistance. 2002. Standar-standar Internasional Pemilu: Pedoman Peninjauan Kembali Kerangka Hukum Pemilu. IDEA.

International DEA. 2002. International Electoral Standards, Guidelines for Reviewing the Legal Framework of Elections. International Institute for Democracy and Electoral Assistance.

Juran, M. J. (1989). Juran on Quality By Design. York: McMillan Company.

Ka'bah, R. (2005). Politik dan Hukum dalam al-Qur'an. Jakarta: Khairul Bayan.

Khaliq, F. A. (2005). Fikih politik Islam. Penerjemah Faturrahman A. Hamid, Jakarta: Amzah.

Mahmasani, S. T.th. Huquq al-Insan fi al-Islam. Cairo: Dar al-Maktabah.

Mahmasani, S. (1982). Adaption of Islamic Jurisprudence to Modern Social Needs in Donohue, J. J., \& John L. Esposito, J. L., eds., Islam in Transition: Muslim Perspectives. Oxford: Oxford University Press.

Megginson, J-M., \& Banfield. (1999). Human Resource Development. London: Kogan-Page Limited.

Miller, P. H. (2000). Theories of Developmental Psychology, 3rd ed. New York: W. H. Freeman and Company.

Mokhsen, N., et.al. (2018). Pengawasan Netralitas Aparatur Sipil Negara, Buku 1, Edisi 1, Komisi Aparatur Sipil Negara.

Nawawi, H. (2006). Manajemen Sumber Daya Manusia untuk Bisnis yang Kompetitif. Yogyakarta: Gadjah Mada University Press.

Nurtjahjo, H., 2006. Filsafat Demokrasi. Jakarta: Bumi Aksara.

Powell JR, G. B. (2000). Elections as Instruments of Democracy (Majoritarian and Proportional Visions). New Haven: Yale University Press.

Pulungan,J. S. (1994). Prinsip-prinsip Pemerintahan dalam Piagam Madinah: Ditinjau dari Pandangan al-Qur'an. Cet. I, Jakarta: RajaGrafindo Persada.

Rusli, M. K. (1991). Pemilu Demokratis Kompetitif. Yogyakarta: PT. Tiara Wacana.

Sjadzali, M. (1991). Islam dan Tata Negara. Jakarta: UI Press.

Tim Redaksi. (2003). Kamus Besar Bahasa Indonesia. Balai Pustaka.

Usman, M. (2000). Kaidah-kaidah Ushuliyah dan Fiqhiyyah. Jakarta: Gema Insani Press.

Wilson \& Heyel. (2000). Hand Book Of Modern Office Management and Administration Service. New Jersey: Mc Graw HillInc. 
Wungu \& Brotoharjo. (2010). Tingkatkan Kinerja Perusahaan Anda Dengan Merit Sistem. Jakarta: Raja Grafindo Pustaka.

\section{Journal Articles:}

Bachtiar, F. R. (2014). Pemilu Indonesia: Kiblat Negara Demokrasi Dari Berbagai Refresentasi. Jurnal Politik Profetik, 3(1).

Haluty, D. (2014). Islam dan Manajemen Sumber Daya Manusia yang Berkualitas. Jurnal Irfani, 10(1)..

Sodikin. (2015). Pemilihan Umum Menurut Hukum Islam. Jurnal Ahkam, XV(1).

Solihah, R. (2018). Peluang dan Tantangan Pemilu Serentak 2019 dalam Perspektif Politik. Jurnal Ilmiah Ilmu Pemerintahan, 3(1).

Winardi. (2010). Menyoal Independensi dan Profesionalitas Komisi Pemilihan Umum Daerah Dalam Penyelenggaraan Pemilu Kepala Daerah. Jurnal Konstitusi, III(2).

\section{Papers:}

Widodo, B. E. C. (2009). Sistem Pemilihan Umum Sebagai Upaya Strategis Untuk Membangun Sistem Politik Yang Demokratis. /320267977_sistem_pemilihan_umum_sebagai_upaya_strategis_untuk_memba ngun_sistem_politik_yang_demokratis_1. Accessed date 16 Oktober 2019.

\section{Internet:}

Anonimous. Netralitas Pegawai Negeri Sipil. https://docs.google.com/ document/d/1svE SXQZsGw01bAlGVPKTZYRJvHRgdMyr158XE 4RsUyU/edit\#!, Accessed 2019, Date 16 Oktober.

Dispen. Netralitas PNS dalam Pilkada.http://dispenmaterikuliah.blogspot.co.id/2011/07/ netralitas-pnsdalam-pilkada.html, Accessed 2019, Date 16 Oktober.

Haris, S., Surbakti, R., Bhakti, I. N., Isra, S., Ambardi, K., Harjanto, N., Nurhasim, M. (2014). Pemilu Nasional Serentak 2019, Accessed from http://www.rumahpemilu.com/public/doc/2019_10_09_executive summary pemilu serentak 2019, pdf.

http://pks.id/content/almuzzammil-desak-komnas-ham-usut-dugaan-pelanggaranham-dalam-pemilu-2019. Diakses tanggal 15 Oktober 2019.

http://www.damandiri.or.id/file/setiawanwicaksonounbrawbab2.pdf Diakses tanggal 15Oktober 2019.

https://docplayer.info/72049773-Sarana-dan-prasarana-kantor.html. Diakses tanggal 15 Oktober 2019.

https://mediaindonesia.com/galleries/detail_galleries/10448-potensi-pelanggaranham-dalam-pemilu. Diakses tanggal 15 Oktober 2019. 
https://www.researchgate.net/publication

Puluhan-kotak-suara-dirusak-di-seunuddon-aceh-utara-diduga-untukgelumbungkan-suara

Rusliandy. Netralitas Pegawai Negeri Sipil. http//rusliandy.blogspot. co.id/2009/06/netralitas-pegawai-negeri-sipil.html. Diakses pada tanggal 15 Oktober 2019

Serambi Indonesia. https://aceh.tribunnews.com/2019/04/28/

Serambi Indonesia . https://aceh.tribunnews.com/2019/04/30/panwaslih-acehutara-perintahkan-perhitungan-suara-ulang-di-geureudong-pasee

\section{Regulations:}

Law Number 7 of 2017 concerning General Elections

Law Number 43 of 1999 concerning Amendments to Law Number 8 of 1974 concerning Personnel Principles 